\title{
A Comparison between Wheel-running and Ambulatory Activities in Young, Adult and Old Rats Based on Long-term Observation
}

\author{
Motoo SHINODA and Toyohiko MIURA \\ Institute of Experimental Animal Research, Gunma University, School of Medicine, \\ 3-39-22 Showa-machi, Maebashi-shi, Gunma 371, Japan
}

(Received 26 May 1993/Accepted 17 August 1993)

\begin{abstract}
It has been considered that spontaneous motor activity (SMA) represented by wheelrunning activity (WRA) or ambulatory activity (AA) is one of the most basic indicators in the behavioral-pharmacological test in small rodents. Since various differences are noticeable between WRA and AA in their characteristics or drug responses, both activities may be not considered as the same category of SMA. The main purpose of this study was to elucidate the background difference between WRA and AA in three different aged groups, based on their long-term observation. AA data obtained by Gundai type Ambulo-drinkometer were applied for comparison with WRA data obtained by Wheel-drinkometer. WRA, AA and drinking behavior all showed clear diurnal rhythms characterized by nocturnal animals under light-dark condition $(\mathrm{LD}=12: 12 \mathrm{~h})$. WRA and $A A$, in particular the former, tended to decrease according to the aging. More than 30 days habituation was required in order to obtain stable daily WRA level in adult rats. AA of young rats was higher than the other aged rats. The present results suggest that indicators, conditions, measurement apparatus, age etc have to be considered in behavioral-pharmacological observations using WRA or AA. KEY WORDS : age, rats, rhythmicity, spontaneous
motor activity
\end{abstract}

\section{長期観察に基づく幼若，成熟および老秢ラットにおける 車回し運動ならびに移所運動活性の比較}

篠田元扶・三浦豊彦

群馬大学医学部附属動物実験施設

\begin{abstract}
一般に, マウスやラット等の小型ゲッ歯類を使用し た行動薬理試験の薬効評価において,これらの動物の 自発運動活性は最も基本的な観察指標となる $[9,10$, 12]。短時間の自発運動測定はオープンフィールド法 によって代表されるような肉眼的観察が基本となる。 しかし, 長時間にわたる連続的な行動観察は肉眼的に は困難であるため, 自動化された測定器が用いられ る。自動化された自発運動活性の測定手段としては, 振動かご, フォトビームあるいは感応電磁誘導等によ る平面上の移所運動活性 (ambulatory activity：AA と略）測定法 $[1,5,9]$, ならびに回転かごを用いて車
\end{abstract}

回し運動活性 (wheel - running activity：WRA と 略）を測定する方法 $[2,7,10]$ が一般に用いられる。 しかし, このような測定方法の違いに起因して, 行動 活性の周波数成分や日周リズムパ夕ーン等の行動特性 $[6,8]$ ，あるいは薬物に対する反応性 [13] が異なる ことが報告されている。また, 同様の測定方法を用い てもラットとマウスの間には動物種差がみられ $[6,8]$, さらに系統差, 日㱓差, 性差等が存在するこ とが推察される。一方, Mizoguchi らにより AA と WRA を同時に観察することの可能な行動量測定ケー ジも試作されている $[4]$ 。このケージは WRA と AA 
を同時に観測でき，WRA 測定時におけるラットのホ 一ムケージ内での行動についても把握できる利点があ る。しかし, 行動特性の分析に関しては, ホームケー ジの大きさがWRAに及ほす影響, あるいは車回し 運動に必然的に伴う学習, 習慣性等がAAに及ほす 影響など未解明の複雑な要因が增えるため解釈が困難 となる。これらの点についての基礎的かつ系統的な研 究はほとんど行われないまま, 両者は「自発運動」と いう名のもとに, しばしば混同されて評価される傾向 がみれる。

本研究では, 種々の日澮のラットを用い, WRAお よび AA, さらに両運動様式に伴う飲水行動活性を長 期間にわたり連続観察し，これらの経日的変化，なら びに日紷経過に伴う WRA およびAAの日周リズム パターンの推移について検討した。そして,これらの 成績をもとにラットの日跲差および運動様式の差（行 動量測定装置の構造の差) がラットの行動活性に与之 る影響, ならびに行動活性を指標とした観察を行う際 の問題点について考察した。

\section{材料および方法}

使用動物および飼育条件：実験に用いた動物は Iar: Wistar-Imamichi 系雄ラット(動物繁殖研究 所, 土浦） 60 匹であり, 室温 $22 \sim 26^{\circ} \mathrm{C}$ に調節された飼 育室にて飼育した。飼育室の照明条件は 6 時点灯, 18 時消灯の12時間明，12時間暗とした。飼料としてはマ ウス, ラット用固型師司料 MF (オリエンタル酵母社, 東京）を用い，飲料水と共に随時捸取させた。実験使 用ラットは観察日齢に基づき以下の 3 群に分類した。 すなわち, 25日跉観察開始, 65日哈観察終了の群, 57

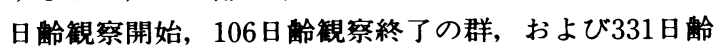
観察開始，380日跲観察終了の群であり，これらを便 宜上それぞれ幼若群, 成熟群, および老橉群とした。

各群とも20匹のラットを用いた。

行動量測定装置：AA および飲水行動活性の測定に は群大式アンビュロ・ドリンコメータ (Model GT831020 , 小原医科産業, 東京) を用いた。本装置の原 理と測定方法については田所ら［12］により詳細に報 告されている。一方, WRA および飲水行動活性の測 定には群大式アンビュロ・ドリンコメータを一部改変 したホイール・ドリンコメー夕 (小原医科産業, 東 京）を用いた。この装置は, アンビュロ・ドリンコメ 一タのケージ部と同寸の回転かご付きケージを作成し
てアンビュロ・ドリンコメータ本体に適用したもので ある [8]。回転かご付きケージはラットの居住部と回 転かごの $2 つ の$ 部分から構成されている。居住部は高 さ $26 \mathrm{~cm}$, 幅 $11 \mathrm{~cm}$, 奥行き $40 \mathrm{~cm}$ で, 飼料箱と飲水装 置が装着されている。回転かご部は円周 $90 \mathrm{~cm}$, 幅 9 $\mathrm{cm}$ で, この回転かごが 1 回転すると 3 カウント計測 するように調整されている。AA およびWRA，そし てこれらに伴う飲水行動活性を 1 時間ごとに自動印字 記録させ, この 3 時間值を用いて日周リズムパターン を描き, 24時間值を用いて1日量の経日的推移を検索 した。

\section{観察項目 :}

1）日跲経過に伴う行動活性の変化：25，57および 331 日䠲の各時点にてラットを上記 2 種の测定装置に 収容し，その後40～50日間にわたる行動活性の経日的 変化について観察した。

2 ) 各群の日周リズムパターン: 各実験群の 24 時間値 が安定した時期における日周りズムパターンを調へ た。日周リズムパターンは $0-3,3-6,6-9,9-12,12-$ $15 ， 15-18 ， 18-21$ おび21-24時の各 3 時間合計値を プロットして描いた。

\section{成}

各実験群におけるWRAおよびAAの平均值の経 日的変化を Fig. 1 に示した。

WRAの 1 日量の経日的変化：WRA は幼若群で初 日に高值 $(5,000$ カウント/日) を示すが, 観察 3 日 目にかけて低下し, その後, 約3,000カウント／日で 安定した。しかし，観察30日目 (54日龄) 頃より著明 な活性の充進がみられ，7,000カウント／日以上に達 した。成熟群のラットは観察初期に極めて低值を示す (1,000カウント/日) が, 観察25３0日目（85日龄 頃）にかけて徐々に活性が立進し，その後高いレヘルル (7,000 7,500カウント/日) で安定した。一方，老 觝群においては, 観察初日の值は1,500カウント/日 と低值を示し, その後さらに減少して, 約500カウン トノ日の值で安定した。

AAの 1 日量の経日的变化：幼若群における AA

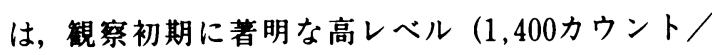
日）を示し，10日以上かけて徐々に低下し，その後, 約150カウント/日の值で安定するパターンを呈し た。成熟群における AA は, 幼若群の安定レベルと ほほ同レベルで観察の初めから終わりまで安定した経 

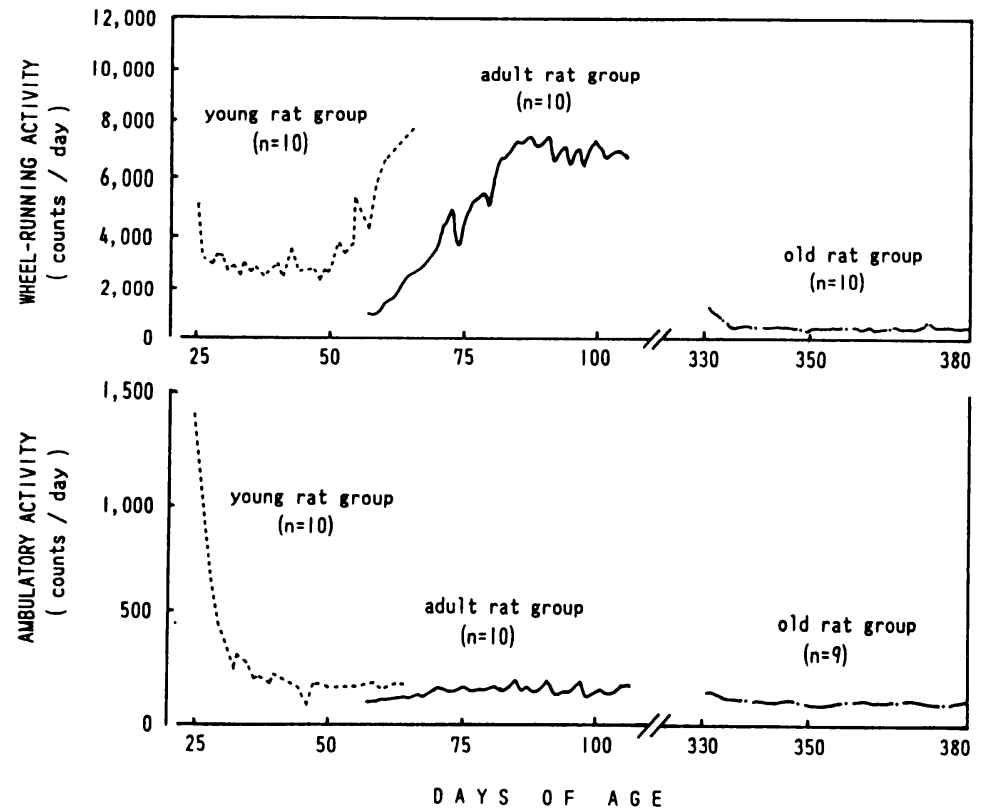

Fig. 1. Temporal profiles in wheel-running and ambulatory activities of young, adult and old rats. For young rat group (----), the experiments were started at 25 days and finished at 65 days of their age. For adult rat group (-), experiments were done from 57 days of their age till 106 days. For old rat group (---), experiments were done from 331 days of their age till 380 days. Each curve indicates their mean activities.
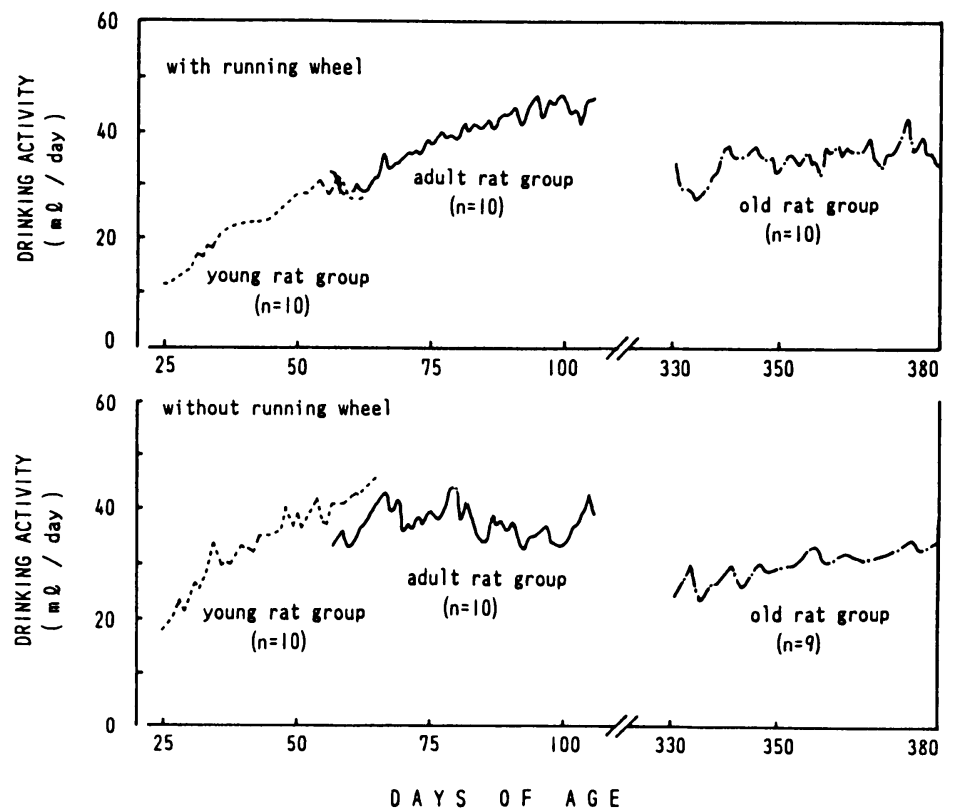

Fig. 2. Temporal profiles in mean water intake by rats with and without wheelrunning activity. Each age group corresponds to that of Fig. 1. 


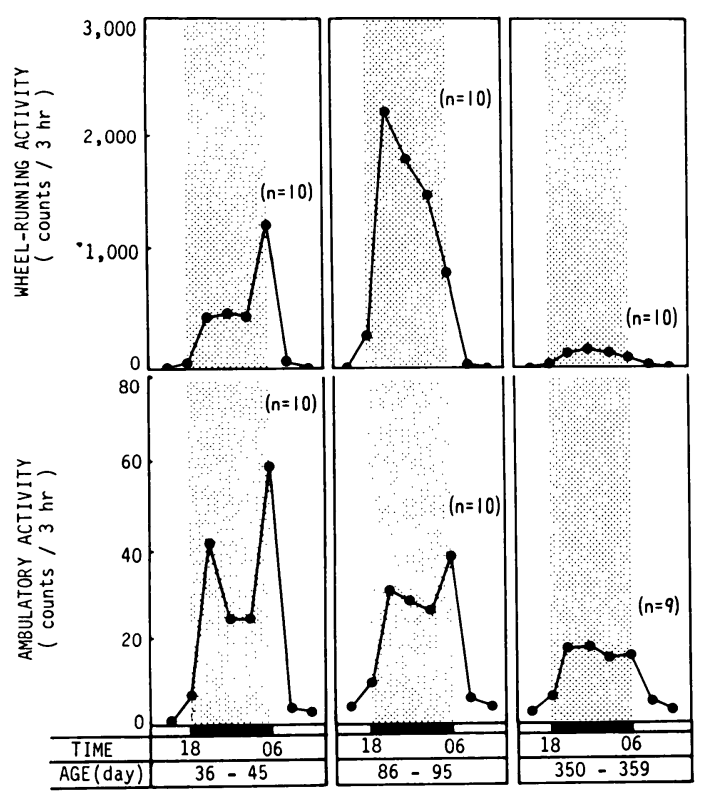

Fig. 3. Diurnal patterns of wheel-running and ambulatory activities in young rat group (36-45 days of age), adult rat group (86-95 days of age) and old rat group (350-359 days of age). Each curve indicates their mean activities.

過を示した。また，老秢群においては，観察初期から 終了時まで著明な低值（50カウント／日）が持続し た。

飲水行動活性の 1 日量の経日的変化：回転かご付き ケージおよび平面ケージで測定した飲水行動活性の 1 日量平均值の経日的变化を Fig. 2 に示した。回転か ご付きケージおよび平面ケージに収容された同一日秢 のラットにおける飲水行動活性の 1 日量の経日的変化 には大きな差は認められなかった。幼若群における飲 水行動活性は, 両ヶージとも日粭経過に伴い漸增した がここれには体重の増加との間に正の相関（回転かご 付きケージ収容ラット $\mathrm{r}=0.79$, 平面ケージ収容ラッ r $\mathrm{r}=0.88$ ） が認められた。また, 老秢群の飲水行動 活性は全般に成熟群より下回っていた。

WRA および $\mathrm{AA}$ の日周リズムパターンの比較：各 実験群の WRA および AAの 1 日量が安定した時期 におけるそれらの平均值をプロットすることにより描 かれる日周リズムパターンを Fig. 3 に示した。各実 験群におけるWRA および AA は暗期に活性が六進 する典型的な夜行性動物の行動パターンを示した。こ れらの行動パターンには日㱓に応じた变化, ならびに

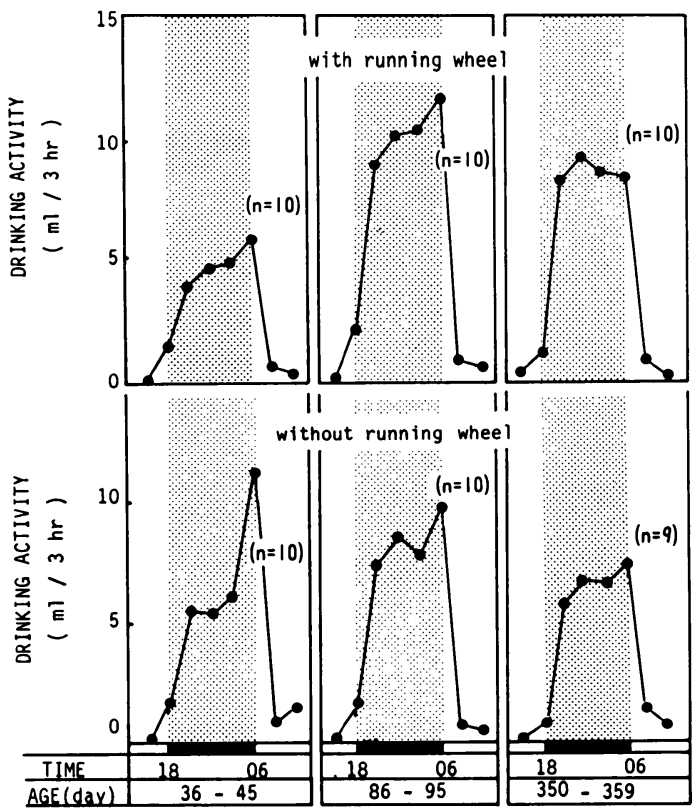

Fig. 4. Diurnal patterns of drinking activities in young rat group (36-45 days of age), adult rat group ( 86 -95 days of age) and old rat group (350-359 days of age) cared with and without running wheel cage. Each curve indicates their mean activity.

測定ケージの構造に基づく相違が観察された。すなわ ち, 幼若群の WRA は 6 時にピークがみられたのに 対し, 成熟群の WRA では21時にピークが出現する 特徴的な単峰性パターンを示した。また，老秢群の WRA は極めて低值を示しており，そのパターンは不 明瞭であった。一方, 幼若群および成熟群の AA は, 21 時と 6 時にピークが出現する明瞙な双峰性パ夕 ーンを呈したが，老粭群では活性の低下がみられ，ま たそのパターンも不明瞭化していた。

飲水行動活性の日周リズムパターン: 各実験群の WRA および AAの 1 日量が安定した時期における飲 水行動活性の平均值をプロットした日周リズムパター ンをFig. 4 に示した。飲水行動活性はWRAおよび $\mathrm{AA}$ と同様に, 暗期に集中した夜行性のパターンを呈 したが, 日秢差, あるいは測定装置の構造差に基づく 影響は少なかった。その日周リズムパターンのピーク は, 回転かご付きケージで飼育した老龄群を除きいず れの群においても大略 6 時に観察された。 
「自発運動」として混同されて評価されることの多 いWRA とAAの日耣に伴う変化およびその日周り ズムパターンの特徴を長期連続観祭により追究した。 この結果, ラットの行動量および活性パターンは日秢 差の影響に加え，AA あるいはWRA という行動の種 類の違いに基づく影響も受けていることが認められ た。すなわち，回転かご付きケージを用いて観察した WRA の経日的変化は幼若群, 成熟群および老秢群の 間で大きく異なっていた。そして幼若群では観察初期 と後期に, 成熟群では観察初期から中期にかけて, ま た老㱓群では観察初期に活性值が大きく变動した。こ のことから, WRA を指標として実験観察する場合,

WRAの 1 日量が安定するまでラットを測定ケージに 慣らす必要があることが明示された。特に箺験に多用 される成熟ラットにおいて WRA が安定するまでに 約 1 か月を要するということは, 実験計画時に念頭に 入れておくべことと思われる。幼若群における観祭 後期の WRA 増加と, 成熟群における観察初期一中 期にかけてのWRA 増加現象は日粭がほぼ一致して いた。さらに老秢群にみられた活性の低下現象を考え 合わせると, WRA にはラットの生涯を通して観察さ れる大きな变動が存在するものと思われる。一方, AA は幼若群の観察初期に極めて高い活性を示した が, 徐々に低下し，その後の值は交定していた。この ような傾向は成熟群および老秢群では認められず, 新 奇環境下での探索行動は幼若ラットにおいてのみ盛ん に行われることが示された。老秢群の $\mathrm{AA}$ は幼若群 および成熟群と比べて低值となっており，ここでも加 粭により運動活性が低下することが示された。なお， 加齢により行動活性が低下寸る現象についてはラット でオープンフィールド法による観察が報告されている が [3]，AA およびWRAの経日的変化ならびに日周 リズムの長期観察報告はない。

本実験期間全般を通してみた場合，WRAより AA の方が経日的变化が安定しており，日秢による影響や 個体差は小さかった。これは平面ケージの構造が単純 化されたものであり，また平面上の移所運動はラット の基本的な生活行動を反映していることによると思わ れる [11]。これに対し，回転かごによるWRAはラ ットの生活行動とは無関係の運動であり, 回転かごに 対する慣れや走行運動に対する興味，学酱等が関らす るため, 日秢差，個体差などが大きく現れてくるもの と考えられる。さらに, WRA および AAの日周リズ ムパ夕ーンにおいても大きな相違がみられた。すなわ
ち，WRAはおおむね単峰性パ夕ーンを示すのに対 し, AA は21時と 6 時にピークの出現する双峰性パ夕 ーンであった。特に成熟群のWRA は21時に最高値 がみられる明確な単峰性パターンを呈することに加 え, AA で最高値の出現する 6 時には暗期における最 低值を示すことなど, WRA と AAの日周りズムパ夕 ーンは全く異なることが示された。このような日周リ ズムパターンの相違の原因については前述と同様,

AA がラット本来の行動様式を示すのに対し, WRA では学習や慣れ等が関与していることに基づくものと 考えられる。さらに, 同じ測定装置 (ホイール・ドリ ンコメータ)を用いても，日齢の相違によりWRA の日周リズムパターンの特徴は大きく異なっていた。 すなわち, 幼若群の WRA は 6 時にピークが出現し ていたが, 成熟群におけるピークは21時に移行してい た。この所見は，加秢が行動様式を变化させる可能性 のあることを示唆しているものと思われる。

一方, 飲水行動の日周リズムパ夕ーンは, 回転かご 付きケージおよび平面ケージに収容したものともにほ ぼ同様のパターンを呈しままた日粆の違いによっても 顕著な変化は示さなかった。このように, 動物の飲水 行動リズムは種々の条件下において安定したものであ り, 動物の行動楽理試験などを行う場合, 飲水行動の ような发定した指標を設けることは，実験の精度を高 める.だ重要なことと思われる。

今回の観察結果から, WRA および AA を指標とす る行動薬理試験を行门場合, 観察指標, 観察条件, 測 定装置, 日秢等を十分に考虑しなければならないこと が示唆された。

\section{要 約}

「自発運動」として，しばしば同義語のように用い られる車回し運動活性（WRA）と移所運動活性 (AA) の差異について, 種々の日秢のラットを用い て, 長期間連続観察を行い検討した。各日秢のラット の WRA および AA は総て夜行性動物特有のリズム パターンを示した。WRA および AA は加粭と共に低 下する傾向が認められ，特にWRA において著明で あった。一般に実験に多用される成熟ラットの WRA はその1 日量が安定するまでには測定装置収容後30日 以上の期間を要した。また，幼若時における AA は 高值であった。以上の結果から，WRA および AA を 観察指標とする行動薬理試験においては, 観察指標, 
観察条件, 測定装置, 日鈤等を十分考虑しなければな らないことが示唆された。

本研究に際し愁切な御助言を賜った群馬県立医療短期大学学 長，田所作太郎博士に深く感謝致します。

\section{文献}

[1] Borbely, A. A. (1976). Sleep and motor activity of the rat during ultra-short light-cycles. Brain Res., 114, 305-317.

[2] Kam, L. M. and Mobery, G. P. (1977). Effect of raphe lesions on the circadian pattern of wheel running in the rat. Physiol. Behav., 18, 213-217.

[3] Kawashima, S. and Kobayashi, Y. (1985). Agerelated changes and effects of long-term administration of chlorpromazine in open field behavior of female rats. J. Sci. Hiroshima Univ., Ser. B. Div., 1, 32, 1 -14 .

[4] Mizoguchi, J. and Ohtaki, T. (1988). A new model cage for simultaneous measurements of wheel-running and ambulatory activity in the rat. Exp. Anim., 37, 85-88.
[5] Norton, S., Culver, B., and Mullemix, P. (1975). Development of nocturnal behavior in albino rats. Behav. Biol., 15, 317-331

［6］岡 基・斉藤 徽・高橋和明 (1984). アウスの自発運動量 の時系列解析. 缺医科学と統計利用, 13, 7-12.

[ 7 ] Stephan, F. K. and Nunez, A. A. (1977). Elimination of circadian rhythms in drinking, activity, sleep and temperature by isolation of the suprachiasmatic nuclei. Behav. Biol., 20, 1-16.

［8］篠田元扶・三浦豊彦・田所作太郎 (1988)。平面ケージおよ び回転かごケージで測定した雌ラットの生活行動りズム の相違について. 実験動物, 37, 463-468.

[9]田所作太郎・栗原久 (1984)。行動稓察の毒性学への応 用. トキシコロジーフォーラム， 7，421-430.

[10］田所作太郎・栗原 久(1990). 薬物の反復投与による行動 効果の修飾. 日薬理誌, 95, 229-238.

（11］田所作太郎 (1980). ラットの生活行動の日周リズム，薬 物と行動, pp. 83-104, 田所作太郎著, ソフトサイエンス 社, 東京.

[12］田所作太郎・栗原 久・白坂和信 - Mohammed Rabiul Alam・藤本憲二(1981).ラットの生活行動リズムの全自動 測定法とその応用. 神䅅精神薬理, 3, 785-803.

[13] 田所作太郎 (1991). 薬物による行動変化. 行動莱理学の 実践, pp.38-44, 田所作太郎編, 星和書店, 東京. 